DOI: 10.1515/ausp-2016-0006

\title{
Literature as Enchantment or the Regained Grandeur of the Novel: An Essay on Salman Rushdie's Novel The Enchantress of Florence
}

\author{
Anca ANDRIESCU GARCIA \\ Valdosta State University (Georgia, USA) \\ English Language Institute \\ aogarcia@valdosta.edu
}

\begin{abstract}
My essay intends to analyze the dialectic relationship between historical reality and fiction in the novel The Enchantress of Florence by Salman Rushdie. I will point out a sophisticated and playful story in which the author interweaves elements of history and literature, a game-story that transcends the canonical limits of postmodernism where the novel has constantly been placed by the critical establishment, and goes back to the beginnings, to the anthropological function of play as an essential human activity that was once defined by Johan Huizinga in Homo Ludens: A Study of the Play-element in Culture. Moreover, my paper will explore how this play becomes Rushdie's attempt to return to the original function of literature which used to enchant and inform at the same time. Once these roots have been reached, however, and the secondary reality of the literary game is well-established, Rushdie manages to break the barriers between reality and fiction, and through versatile textual mechanisms, to intermingle history and reality in a way that makes them merge. Consequently, he composes a play within fiction that is just as powerful as reality itself and suggests the fact that representation has more ontological consistency than the represented body or event itself. We exist as long as we are written and talked about, and nothing in the order of reality can be as powerful as the reality of language.
\end{abstract}

Keywords: Rushdie, reality, history, representation.

\section{Critical Perspectives}

Salman Rushdie's tenth novel The Enchantress of Florence has received over time a multitude of mixed reviews. While the majority of the critics agree that the novel is definitely not of the same caliber as the masterpiece Midnight's Children and even accuse it of redundancy of themes and literary motifs, they also have to admit that we are facing the novel of a great writer, a novel that would have 
probably deserved the Man Booker Prize the year it was published, 2008, with Andrew Anthony's interview with Rushdie in The Observer and John Sutherland's review in the Financial Times being clear supporters of it. Other interpretations, such as William Deresiewicz's essay in The Nation or the excellent study on Rushdie's work edited by Robert Eaglestone and Martin McQuillan, are more reserved and discuss the image of the storyteller or the subtle relationship in the text between reality and imagination, while others, such as Andrew Martino in World Literature Today criticize the novel for parts that lack quality or depth. As my interest lies exclusively in the dialectical game between history/reality and fiction/imagination, I cannot say that Rushdie's novel disappointed me; on the contrary, it is one of the most interesting examples of such a relationship that I have ever read. Therefore, in my overview of its critical reception, I will explore three categories of texts some of which I mentioned above - interviews and confessions, reviews, and longer studies or parts of longer studies about Rushdie before I commence my own research. The two main objects of this overview will be the idea of play with its variants, game and enchantment, and the relationship between reality and fiction (imagination, illusion, or magic as some of the analysts call the latter). I will also connect these critical points of view to the texts I will use for my own analysis, which do not refer to the novel per se, but explore the world of play and the difference between reality and fiction.

Among Rushdie's interviews about his work and the novel The Enchantress of Florence, three of them are particularly important, especially because they were broadcast or published for wide audiences. The first is the interview conducted by Robert Siegel for All Things Considered on NPR, on May 27, 2008, in which Rushdie explains how certain characters in the novel are "figments of other characters' imagination" (Siegel 2008), the motif of Pygmalion that this idea is based on, the hybridity of a character such as Johda who is unclear to have even existed in reality, and the fine line between reality and fiction. Later in the same interview, the writer points out an idea that will be discussed at length by many of his reviewers: mainly that he thinks "all the stuff that people will think of as magical realism [...] is actually in the historical record [...]. And vice versa - all the stuff that people will assume is real" is actually fictional (Siegel 2008). The same idea had been discussed in April earlier that year when in an interview for the British magazine The Observer, Rushdie claimed that "a lot of [the novel] is true [...]. All kinds of stuff that I suspect people will assume is magic realism, isn't” (Anthony 2008). Later that same year in an interview for Charlie Rose, Rushdie deplores the inaccurate use of the term "magical realism," in which, he says "what [people] hear is magical and what they don't hear is realism," and addresses the ambivalence of the famous historical characters in a novel which have to be made up but at the same time still have to be "faithful to the historical record" (Rose 2012). The main downfall of these interviews is the fact 
that they are destined for a wide public, and thus the author cannot venture too far into the theoretical background of his novel, but even so, it is clear from all of them that Salman Rushdie is permanently preoccupied with the veridicity of the representation of history and has tried repeatedly to defend the connection between his writings and reality. He always feels the need to make clear that many times his texts incorporate truth that is very often mistaken as magic. When the interview genre boundaries do not apply, Rushdie becomes even more explicit, as he does in his memoirs, this time referring not only to a historical, but also to a geographical connection. This is Rushdie speaking about himself in the third person in Joseph Anton:

He needed to connect those worlds to the very different world in which he had made his life. He was beginning to see that this, rather than India and Pakistan or politics or magic realism, would be his real subject [...] the great matter of how the world joined up, not only how the East flowed into the West and the West into the East, but how the past shaped the present while the present changed our understanding of the past, and how the imagined world, the location of dreams, art, invention and, yes, belief, leaked across the frontier that separated it from the everyday, 'real' place in which human beings mistakenly believed they lived. (2012, 68-69)

But if Rushdie sees his literature as a way to change human perceptions, this idea may contrast with another reference to his own writings in the same interview with Anthony mentioned above, when he claims that he just wants "to stay at home and write stories and send them out every couple of years. That's why [he] got into the game" (Anthony 2008). Is literature for Rushdie a space in which everything falls into place, reality and imagination coexist, contraries disappear, past and present connect, or is it a place of play, or both?

One possible answer belongs to Kenan Malik in his "Foreword" to the highly acclaimed study on Rushdie's work edited by Robert Eaglestone and Martin McQuillan. Malik argues that "the truth that emerges from Rushdie's writing is the truth of the experience of that in-between world, the world of migration and mélange, belonging to more than one place, multiple rather than singular" (2013, viii). The writer allows the imagination to change the real world by "forcing ideas, and memories, and thoughts and histories to clash with each other" (2013, viii). The critic suggests that the real force behind Rushdie's novels is this emphasis on the power of imagination, but he does not elaborate where exactly this power leads. Neither does Marianne Corrigan in the third chapter of the same study when she discusses, following Mads Rosenthal Thomsen's theory, the link between Felix Guattari and Gilles Deleuze's concept of rhizome and Rushdie's fiction. However, in spite of the fact that Rushdie's novel contains 
indeed a "plot that travels across continents from the Mughal court of Akbar to Renaissance Florence, while simultaneously engaging with the cultural and philosophical ideas of the historical periods in question" (Corrigan 2013, 42), I think the novel remains a one-dimensional, highly organized world in itself, and the rhizomatic model would only complicate the discussion surrounding it. Putting together these very distant and distinct elements of geography, culture, and historical periods means for Rushdie more than the call of multiculturalism or postcolonialism, or any -ism for that matter, including postmodernism, ${ }^{1}$ to which his work is usually attributed, but rather an attempt to tell what Martin McQuillan calls in the same study "a story about storytelling and the intrigue it engenders" $(2013,82)$. As strange as it may seem, this "phenomenalization of reference" as the same critic later names the ambiguous fictional nature of some of the characters as Qara Köz, shows that, for Rushdie, literature is "a space where the tension real-unreal remains as a constant question that predicates reading" $(2013,97)$.

McQuillan's opinion is not singular. Several reviews of the novel, written right after its publication, seem to follow the same line of thought. One example is JoAnn Conrad's essay which argues that in The Enchantress of Florence there is "no clear-cut boundary between reality and fantasy," yet historically and geographically Rushdie "is not so much fictionalizing this interconnected world [that spreads on several continents], but bringing it to light" $(2009,433)$. Mogor's story is the "central puzzle of the book" (Conrad 2009, 434) and, just as in the 1001 Nights, his outside frame includes many other interconnected stories as well. The novel is thus, in Conrad's opinion, an interrogation of "the nature of narrative and the specifically human tendency to narrate and thus fabricate reality" $(2009,436)$. In a review of the novel published in The Atlantic, Rushdie's friend Christopher Hitchens writes in his turn that "the worlds of illusion and enchantment seem to collapse in upon themselves, leaving a rich compost of legend and myth for successor generations" $(2008,135)$. He also notices, very importantly, the presence of the element of water as a central image of the story to which, as Hitchens points out, "all potentates and serfs are in the end equally subservient" $(2008,136)$, an image that in my opinion has a multitude of possible interpretations which I will review later. For John Sutherland in "Of Medicis and Mughals" there is "more magic than realism" (2008) in Rushdie's novel, but the reviewer does not give any further explanation of how the two of them relate, while for Martin Tucker in Confrontations "Rushdie's fascination - or obsession - with the reality of illusion plays a climatic role in the novel," one example of how this fascination materializes being the character of Qara Köz who "exists as

1 Here I am talking about Linda Hutcheon's considerations on Rushdie in The Politics of Postmodernism which I decided not to use for my paper because first they are a very beaten path, and second I do not think the techniques described there even apply to this novel. 
surely as those she inspires. It is their belief which sustain her, and their vision she inspires" (2009, 214).

There are, of course, critical voices, such as Andrew Martino or Justin Neuman, who talk mainly about the novel's downfalls. For Martino The Enchantress is "at best a wonder of intertextual thought, and, at worst, a burdensome game [in which] postmodern calisthenics defeat the number one rule of storytelling: keep the reader captivated" (2009, 70-71). Neuman goes even further and declares that the novel "eschews the significant stylistic innovation and overt, high stakes cultural commentary that energizes Rushdie’s The Satanic Verses” (2008, 675). The critic notices, however, the importance that the motif of the mirror has in the novel, an importance analyzed in depth by D.C.R.A. Goonetilleke as well in his study on Rushdie, but which is for Neuman "a mirror veiled with gauzy multicultural platitudes" (2008, 675). Nevertheless, Neuman's essay has the merit of offering a deeper explanation for the dialectical relationship between reality and fiction in Rushdie's work. As he asserts, "fiction and narrative are powerful transformative forces; narrative is less a means of representing the world than a mode of apprehension, a metaphysical hammer he uses to smash certainties of causality, a forge of the alternate real. For Rushdie, fictions are the world entire" (2008, 680). While I fully agree with Neuman's view on the narrative force that builds a new world in its entirety, I am not satisfied with the way the description of this alternate reality is suspended, and with the fact that the critic does not go further in his interpretation of the self-referentiality of the novel which he considers again a series of "platitudes and pomposity" (Neuman 2008, 682). Finally, in a more moderate tone, William Deresiewicz observes that Rushdie "seeks to reanimate the printed page" and places in the center of the novel "storytelling [in] itself" (2008, 34). Deresiewicz further asserts that even if the novel "exhibits none of the complex allegorical structures, dense systems of allusions or broad political implications - in short, none of the satanic ambition - that both weigh down his major work and give them weight, [it] is probably Rushdie's most coherent and readable novel” $(2008,34)$. The writer, as Deresiewicz rightfully observes,

never fully commits to the magic-realist premise, a hesitation that makes his practice more sophisticated and less satisfying. [...] Rushdie is also testing [in The Enchantress] the power of imagination to affect reality. This is his highest theme, his persistent obsession. If so much of what seems magic at first turns out to be the result of art or artifice, that is exactly the point. $(2008,35)$

Indeed, Rushdie's novel does seem to bring imagination and reality together, trying at the same time to demonstrate the impact the first has on the other. It is a double process though, a play of mirrors that can go both ways. None of the 
reviews above answers, however, the question of purpose - why does Rushdie go to such great lengths to combine reality and imagination? Why does he choose this particular way to connect cultures and historical figures under the spell of fiction? Is his novel, as I asked at the beginning of my essay, a place where reality and imagination influence each other antagonistically or do the two of them coexist? How are that tension or coexistence connected to the idea of play, as some of the reviewers discussed it, or "game" as Rushdie himself called it? For a possible answer to all these questions I turned to two studies - one is Johan Huizinga's Homo Ludens: A Study of the Play-element in Culture, which analyses the origins and the manifestations of play in culture, and the other is Virgil Nemoianu's study Imperfection and Defeat: The Role of Aesthetic Imagination in Human Society, an essay on the relationship between fiction and reality.

\section{Play and Reality}

Huizinga's study analyzes the nature of play as a cultural phenomenon from an anthropological point of view. In "Chapter I: Nature and Significance of Play as a Cultural Phenomenon," he observes that "play is older than culture" because man is not the only being that plays $(1950,1)$. He consequently discusses its main features. First of all, "play" is not a material activity because it has a supralogical nature that breaks the "absolute determinism" $(1950,3)$ of real life, and therefore it is essentially different from it. Second, since play existed even before the creation of culture, it becomes an inherent element of it, accompanying it through all the stages of civilization and through all "the great archetypal activities of human society" $(1950,4)$, such as language - even metaphor is a play upon words - myth, literature, etc. Thirdly, "play is based on the manipulation of certain images, on a certain 'imagination' of reality [and] it is the direct opposite of seriousness" $(1950,4-5)$, as it is usually seen as fun, yet the rules of the game are serious for its participants. It "lies outside the antitheses of wisdom and folly, and equally outside those of truth and falsehood, good and evil" $(1950,6)$. Play, the Dutch anthropologist continues, is always a voluntary activity, one beyond duty, one that is essentially free, and limited only in terms of time and place; its time and place are well-defined and distinct from ordinary life. The fact that play is distinct from ordinary life also implies its repetitiveness and its ability to create its own order, an order, explains Huizinga later on, which has strict rules, so anyone who trespasses them immediately destroys its elaborated structure. Moreover, "the words we use to define elements of play belong for the most part to aesthetics [...] play casts a spell over us; it is 'enchanting', 'captivating'", (Huizinga 1950, 11). It likes to surround itself with secrecy and it has an element of tension as well, the tension of trying to achieve something difficult. Finally, 
play has the ability to bring people together, "it promotes the formation of social groupings" (Huizinga 1950, 13); it is "indispensable for the well-being of the community" (Huizinga 1950, 26), a sacred sphere where the child, the savage, and the poet feel equally at large. In "Chapter VII: Play and Poetry," Huizinga talks about poiesis as a play-function, a play of mind. Ancient poetry was equally "ritual, entertainment, artistry, riddle-making, doctrine, persuasion, sorcery, soothsaying, prophecy, and competition" (Huizinga 1950, 120). The poet is a poeta vates, the possessed and the voice of God, but by reciprocity also the one who possesses the knowledge of the world. Throughout history, his image ranges from prophet to priest, from sorcerer to philosopher, from rhetvor to the buffoon or jester. An analogue to the play which has certain "limits of time and space, in a visible order, according to rules freely accepted, and outside a sphere of necessity and material utility," poetry in particular, and, I would add, literature in general, is an "arrangement of language, [...] the deliberate disguising of sense, the artificial and artful constructions of phrases" (Huizinga 1950, 132). The writer's goal, in Huizinga's terms, is to "enchant the reader and hold him spellbound" (1950, 132). As I will demonstrate, all these features apply to Salman Rushdie's novel.

Apart from the analysis of the mechanism of play, another interesting aspect in Salman Rushdie's novel is the way this mechanism interacts with reality, so I based this second part of my essay on a theory belonging to Virgil Nemoianu which discusses particularly the dialectics of historical progress/reality versus literature/fiction. This distinction, which, as I pointed out above, is mentioned frequently as the main theme of The Enchantress of Florence, does not seem to be fully explained by other studies. Nemoianu's text investigates precisely this relationship between reality and its textual reflection in literature and argues that in the course of historical evolution certain elements are lost and defeated, certain parts are inevitably imperfect, and this imperfection is the domain of literature. In other words, the role of literature is to warn of the existence of imperfection and to attempt to organize it, because otherwise the human consciousness will not be able to function. Progress is a sum of human efforts to shape and organize reality in a homogeneous unit, but homogeneity "is closely akin to death" (Nemoianu 2006, 8). The secondary, on the other hand, preserves the heterogeneity, and in its reaction to it manages to reestablish "the very possibility of vitality and survival" (Nemoianu 2006, 8). A literary text is characterized through multiple meanings and textual openness, a quality that scientific texts do not acquire, even though some of them do become more literary with the passing of time. In what we generally define as progress, the principal and the secondary coexist, and there is a permanent mutual transformation between the two, but the first is dominant and the second is its antagonist. Nemoianu compares this relationship with what Mircea Florian called "recessiveness:" an interaction in which one dominates the other (and the domination can always be reversed), synthesis is impossible, 
and there is always a tensional coexistence between them (Nemoianu 2006, 14). Literature "tends to collect what is abandoned and discarded" (Nemoianu 2006, 16) - in other words the imperfection - and reintroduces it while opposing orderly progress. Basically, it restores what was missed by history; progress becomes a matter of indifference, and the text can include imperfections. Its conflict with history relies precisely in its compromising and synthetic nature, which contradicts the nature of rationalism, politicking, and the historical reality. As literature does not have to obey the rules of the political establishment, "the role of the writer and artist in [a pluralist] society is simultaneously that of a conservative" (Nemoianu 2006, 26), and of an opponent of the ideology of the day. Good literature "unmasks and subverts its own prevailing ideology. In doing so, it provides for the preservation and transmission of values for keeping the historical process open" (Nemoianu 2006, 30).

Huizinga's study and Nemoianu's considerations are useful especially because they can offer a broader perspective on the nature of the relationship between reality and fiction in Salman Rushdie's The Enchantress of Florence. Therefore, I have decided to use both of them in my analysis below.

\section{Play in Literature}

The Enchantress of Florence is not only a historical novel, but also a meditation on the role this type of novel in particular, and the representation of history in general have in culture. The beginning of the text marks the entrance in the territory of fiction. The traveler is in the liminal space between of the world and the city, and his every step is marked in a language that deserves to be quoted fully:

In the day's last light the glowing lake below the palace-city looked like a sea of molten gold. A traveler coming this way at sunset - this traveler, coming this way, now, along the lakeshore road - might believe himself to be approaching the throne of a monarch so fabulously wealthy that he could allow a portion of his treasure to be poured into a giant hollow in the earth to dazzle and awe his guests. And as big as the lake of gold was, it must be only a drop drawn from the sea of the larger fortune - the traveler's imagination could not begin to grasp the size of that mother ocean! (Rushdie 2008, 5)

As the sun sets, the sea of gold proves to be an illusion, and it is reduced to a simple lake, with the water being the only remaining "treasure to offer" (Rushdie $2008,5)$. Some might call this a return to reality from magical realism, but I think this episode is meant to signify something completely different: namely that the description has reached its goal. Through the "manipulation of images" 
as Huizinga once put it, we have entered not only the territory of fiction, but also the territory of play, or rather, the two of them are equivalent here. It is not random, therefore, that water was chosen to be the barrier for such a passage; with water we are talking of a space of "play" different from the space of real life, a space with a life of its own. Water is an archetypal element with a dual nature - it is primordial, and it can make life appear, but it can also be deadly for those who trespass its boundaries unprepared. Water in Rushdie's novel allows a fluid passage between empirical reality and the play of literature, but it does not necessarily mean a farewell to the first and the beginning of life for the other. It becomes a metaphor of the flexibility of the literary play capable of incorporating but also producing reality; and this is the very reason the writer defends the realism of his novel. Its importance is clear throughout the whole text as it is always referred to in the most important moments, sometimes even mentioned to be the real ruler of the world, because "even an emperor, denied water, would simply turn to dust" (Rushdie 2008, 8).

Not surprisingly, the thirsty traveler accepts the gift of water, and thus he symbolically completes his arrival in the city, a place of trade and commerce, an obsession in Rushdie's novels as Deresiewicz once noticed (2008), but a place that, just like play, brings people together. His situation, gestures, and appearance are in the beginning hilarious at best, but as the description unfolds, the irony is replaced slowly by seriousness. He travels in a bullock-cart, a risible means of transportation, yet he progressively instills admiration into the puzzled driver as he stands like a god wearing "a fool's unsuitable clothes" but "a graceful fool," nevertheless, "or perhaps not a fool at all" (Rushdie 2008, 6), a stranger, as the driver says to himself later, who seems "not so foreign [...] after all" (Rushdie $2008,6)$. This description of the main character who belongs to the space of fiction, seen as a fool, or even a jester, a magician, or a sorcerer in the following episodes of the novel, places him outside the antithesis of wisdom and folly mentioned earlier by Huizinga, just as the rules of the play require. As he attains more and more centrality in the novel, his image tends to juxtapose with that of the poeta vates, the owner of knowledge, and the enchanter who is meant to keep the reader spellbound. We are far away here from Mario Vargas Llosa's traveling storyteller who was supposed to save the world of the Machiguengas with his stories; in The Enchantress of Florence we only have a storyteller who is very aware and in full control of his magical abilities, of the rhetorical mechanisms of language, and intends to use them to make his way through to the emperor and the reader alike. He tells the bullock-cart driver that he is in the possession of a secret meant only for the kings, another sign of the presence of play which in the early rituals was supposed to surround itself with secrecy while it was performed by masked or disguised players, and, as we go further in the novel, we read about the nature of this disguise: he stole a diplomatic document from 
a Scottish milord, in fact a former pirate suddenly turned into an emissary of the Queen of England, and he pretends now to be the rightful representative of the British Empire at the court of the Indian emperor Akbar the Great. This secret will be just a means to an end, a way to grab Akbar's attention; his other secret, a distant claim to the throne, will be revealed far later in the novel. What is important for now is that, as the traveler falls asleep, he has the world of play and fiction in his mind:

As soon as he fell asleep half the world started babbling in his brain, telling wondrous travelers' tales. In this half-discovered world every day brought news of fresh enchantments. The visionary, revelatory dream-poetry of the quotidian had not yet been crushed by blinkered, prosy fact. Himself a teller of tales, he had been driven out of his door by stories of wonder, and one in particular, story which could make his fortune or cost him his life. (Rushdie $2008,10)$

Apart from the motif of Scheherazade which is obvious in the text and has been mentioned before by various critics, Rushdie's novel seems to follow extremely closely Huizinga's recipe: the enchanter is there ready to exhibit his sorcery and even compete with the divinity - hence, for example, the episode in which Mogor / Ucello di Firenze multiplies "fishes and loaves with a couple of passes of his elegant hand" (Rushdie 2008, 12) - and to create a second, more poetic world different from the real one but not necessarily opposing it. The space and time are also clearly delineated: the place of the story, the time of Akbar combined later in the novel with Florence in the time of Machiavelli, the freedom with which characters move and invent themselves or others, all are there too. The novel becomes a magic circle, an arena of thought with its own special rules, a temporary world within the world of reality. The secret the storyteller carries with him is a play within language, but also a play of life and death, which brings this language close to its biblical meaning. It can help him get to Akbar, and in this point the novel is a demonstration of linguistic virtuosity, but it kills Lord Hauksbank, and it kills Ucello symbolically when Mogor abandons that name as if he would leave behind the "skin of a snake" (Rushdie 2008, 23). As a matter of fact, it almost kills Mogor too who ends up in Akbar's prison, but saves him at the same time when he realizes that his only mission is to tell his story because without the story he would cease to exist:

He would die without telling his story. He found this thought intolerable and so it refused to leave him, it crawled in and out of his ears, slid into the corners of his eyes and stuck to the roof of his mouth and to the soft tissue under his tongue. All men needed to hear their stories told. He was a man, but if he 
died without telling the story he would be something less than that, an albino cockroach, a louse. The dungeon did not understand the idea of a story. The dungeon was static, eternal, black, and a story needed motion and time and light. He felt his story slipping away from him, becoming inconsequential, ceasing to be. He had no story. There was no story. He was not a man. There was no man there. There was only the dungeon, and the slithering dark. [...] He would not rest in peace. In death as in life he would be full of unspoken words and they would be his hell, tormenting him through all eternity. [...] The most beautiful woman. The story was saving his life. (Rushdie 2008, 89-90)

Paradoxically, Mogor is a copy of Scheherazade, but at the same he is not. He relies on his storytelling to stay alive, but, unlike his predecessor in 1001 Nights, he understands that the story is not a burden he has to perform out of duty, and he sees it as the art it really is, an art that creates and destroys characters, images, places, empires, but an art in the absence of which the memory of humankind itself would disappear. The idea is not new - even in Beowulf we are told that immortality is on "men's lips" - but here in Rushdie's text, which comes after an entire line of writers and philosophers who attempted to deconstruct the ability of literature to create new meaning, to abolish its value, and to deny the writer's power of imagination, this is quite an interesting move. It is not a very surprising one, however, for someone who openly declared that he wants to stay in the game of literature, to be left alone so he could write stories. He understands that he needs to create a tension, as Huizinga defined it, to play with images and characters, to work within the limits of the imaginable and instill mystery in the story, so he can keep the reader committed. Basically, in this point, the writer himself becomes an enchanter.

The same is also true for Akbar because the only true enchanters in the story, apart from the story itself which becomes a vehicle for the writer's enchantment, are Mogor and Akbar. Of course, one can argue that the real enchanter in the novel is the enchantress Qara Köz / Angelica; after all, even the title is dedicated to her. But I have doubts that this is really the case as she is ultimately just a character in Mogor's story. Akbar is probably the most powerful enchanter in the text, even more powerful than Mogor/Niccolo Vespucci, although the latter provides the frame to keep the story together, because Akbar, mirroring the writer at another level, is also in the possession of power. In fact, the narrator admits it: "he was the Enchanter. In this place he would conjure a new world, a world beyond religion, rank, and tribe. [...] An emperor was a bewitcher of the real, and with such accomplices his witchcraft could not fail” (Rushdie 2008, 43). Through his power he can not only enchant, but also manipulate reality, as it is the case with Jodha, one of the most interesting characters in the book. As Rushdie observes in his interview with Robert Siegel mentioned above, it is unclear if Jodha has 
ever existed as a historical figure, although she is mentioned by history books as Akbar's Hindu wife. Rushdie concludes, however, that she does not have enough historical consistency, so he recreates her in the novel not as a real person, but as the product of Akbar's imagination. His decision to make her come into being, and the process that follows it, remind us indeed of the myth of Pygmalion, but goes even further than that:

she had heard from the emperor a traveler's tale of an ancient sculptor of the Greeks who brought a woman to life and fell in love with her. That narrative did not end well, and in any case was a fable for children. It could not be compared with her actual existence. Here, after all, she was. She simply was. Only one man on all the earth had ever achieved such a feat of creation by pure act of will. (Rushdie 2008, 47-48)

Her influence grows as art helps her acquire more existence, "Tansen wrote songs for her and in the studio-scriptorium her beauty was celebrated in portraiture and verse. Master Abdus Samad the Persian portrayed her himself, painted her from the memory of a dream without even looking upon her face, and when the emperor saw his work he clapped his hands at the beauty shining from the page" (Rushdie 2008, 28). In other words, Johda's creation is a self-referential artistic act equivalent to a mise en abyme ("the memory of a dream"). Still following closely the rules of the play, the novel undermines the barriers between truth and falsehood and situates itself beyond their antithesis. Rushdie's choice for a historical novel is not, therefore, surprising at all; for him history is imperfect because none of the accounts about a certain historical figure is complete, but in the space of the novel this imperfection is annulled because a character does not have to prove its authenticity. After all, it does not really matter if Jodha has existed or not. In the end, even after people's physical death, there is no reality other than the word reality; they continue to exist only if they are spoken of: "in the end her victory will be apparent to everyone, for in the end none of the [real] queens will exist anymore than she does, while she will have enjoyed a lifetime of your love, and her fame will echo down the ages" (Rushdie 2008, 45). Similar to Johda, who knows she simply is, is play. It can exhibit its mechanisms, but that does not mean they need to be explained. Just as for Chaucer before him, the product of imagination can become for Rushdie more real than real life itself, and it can contain more meaning. Since play is not a material activity and its nature is supra-logical, it does not matter if such an operation is justified. Thus, what many critics have considered an array of intertextual platitudes, is actually Rushdie's idea of freedom in building a historical character.

The same freedom manifests itself again in the case of Akbar's contrasting personality features. As it has been observed before, Akbar himself is a sum of 
paradoxes. He is described as "a Muslim vegetarian, a warrior who wanted only peace, a philosopher-king: a contradiction in terms" (Rushdie 2008, 45). We find him throughout the novel striving to become, trying to balance the different parts of his personality or his different duties, dealing with relatives' betrayals, falling in love and being enchanted by one figment of imagination after the other - Johda, Queen Elizabeth of England, Qara Köz/Lady Black Eyes/Angelica - and also being genuinely interested in the life of his subjects and in the life of the other city that he manages to travel to through Mogor's stories, Florence. There is, however, a very interesting moment in his trajectory, the moment when he desperately tries to abandon the pronoun We, the plurality reserved only for the emperors, and reduce his persona to the singular pronoun $I$ :

He was the definition, the incarnation of WE. He had been born into plurality. When he said 'we,' he naturally and truly meant himself as an incarnation of all his subjects, of all his cities and lands and rivers and mountains and lakes, as well as all the animals and plants and trees within his frontiers, and also the birds that flew overhead ... he meant himself as the sum of all his victories, himself as containing the characters, the abilities, the histories, perhaps even the souls of his decapitated or merely pacified opponents; and, in addition, he meant himself as the apogee of his people's past and present, and the engine of their future. [...] Perhaps this idea of self-as-community was what it meant to be a being in the world, any being, such a being being, after all, inevitably a being among other beings, a part of the beingness of all things. Perhaps plurality was not exclusively a king's prerogative. (Rushdie 2008, 31; emphasis and ellipsis in the original)

At this point the novel challenges the boundaries of its genre. It states that a novelistic character, a historical figure, and, ultimately, any human being have one thing in common: they all depend on the way they reflect themselves in the minds of others. Therefore, Akbar cannot transgress his status and become one-dimensional. No matter how much he tries, he is not allowed to become a singular person: he remains all of them in the novel - a character, a historical figure, and even a man - and perceives this idea as traumatic. He is a plurality "in the eyes of the world" (Rushdie 2008, 52), a metaphor of the fact that, as in Johda's example too, characters, and historical figures, no matter how well known or documented, cannot escape the countless possible interpretations which the world bestows on them. The play, the novel, the historical figure, the work of art in general can be seen again, repeated or revisited, and with each time they acquire a different meaning. Again this is not a very new idea; it is recurrent in the works of the philosophers of postmodernity, from Jean Baudrillard to Francis Fukuyama, but in Rushdie's novel the fact that such an endeavor is attributed to a 
Mughal emperor is indeed unique. So is the fact that he feels utterly alone in his meditation. Not even Johda, the perfect queen, the product of his imagination, is capable of understanding it. She is too focused on the problems concerning her own existence, on her possibility to stay alive even without his help:

The question of her independent existence, of whether she had one, insisted on being asked, over and over, whether she willed it or not. If God turned his face away from his creation, Man, would Man simply cease to be? [...] Was her will free of the man who had willed her into being? Did she exist only because of his suspension of disbelief in the possibility of her existence? If he died, could she go on living? (Rushdie 2008, 49)

This point marks the end of their relationship. Akbar learns his lesson and will never refer to himself otherwise than plural, and he gets a companion in his counterpart/enchanter/storyteller Ucello di Firenze/Mogor dell'Amore/Niccolo Vespucci, who just like him, although not always so evident, is another pluralistic personality, this time one built exclusively on his own stories meant for others to read and make them complete. Like two chess players, they will accompany each other throughout the rest of the novel, with Akbar almost determined to name Niccolo his successor at some point.

All of this said, some questions still arise. What is the real purpose behind all this complicated mechanism of "play" within history and fiction? Is Rushdie's only goal to show the dissolution of the barriers between imagination and reality, to put them both sub specie ludi, or just to write a novel that demonstrates, as many analysts have said before, the fact that the world of illusion is stronger than the real one? Or to even unify in a playful, and very postcolonial manner the East and the West, and two different historical periods in one place and time?

Indeed, it seems that way at first. With Machiavelli, Botticelli, Andrea Doria, Amerigo Vespucci, Lorenzo de' Medici, Simonetta Cataneo as historical figures, with Nicollo Vespucci, Qara Köz and Argalia as fictional characters that create the links between them, with the action unfolding in two placeable, recognizable cities such as Fatehpur Sikri and Florence, and even with the impressive bibliographical exhibit at the end, The Enchantress of Florence could be just another example of a historical novel which, as Virgil Nemoianu defines it while referring to Walter Scott's work, has established even from the beginning of the genre a generic rule according to which "the main and well-documented historical characters ought to function as secondary fictional characters in the background (or obliquely referred to), while secondary or outright invented historical figures are the ones who function as a foreground" (Nemoianu 2006, 75). The distinction between literature, which Nemoianu calls secondary, and historical progress appears to be in place too; Akbar's hesitations, the episode 
with Rana, Argalia's defeating Vlad the Impaler which fills a historical gap since Vlad's real opponent is not known, the story of the hidden princess Qara Köz/ Lady Black Eyes/Angelica who manages to connect all the continents together in her travels; every one of them are possible examples of the imperfection of the secondary because literature is meant, as Nemoianu suggested, to recuperate what was lost or defeated and thus challenge history, and to stir up the complacencies of linear progress by reintroducing those elements. Rushdie seems indeed to use the freedom of the fictional text to explore the psychological and cultural motivations behind the acts of recognizable historical figures, and in the case of Akbar he appears to pursue the process through which literature alters the signified from an individual, as a sum of characteristics documented by historical records, to "human by adding retrospection to reality" (Nemoianu 2006, 20). Also, if we follow Nemoianu's argument, the novel would elicit a clear distinction between literature and history because the two of them are never meant to merge completely; they are only destined for tensional coexistence, for a relationship of recessiveness which puts them in a condition of inequality. This would explain the fervor with which Rushdie's novel was interpreted as a triumph of imagination over reality, a flip between two worlds, a magical realist tale with nonconformist historical conjunctions.

\section{The Sacred Function of Literature}

However, this interpretation elicits a few technical problems. The first and the most important one is that, if the highlighting of the antagonistic relationship was the real purpose of the novel, the idea of a textual play loses its significance, as it makes no sense to build a separate world with its own time, space, rules, enchanters, mythology, etc., if one only wants to oppose the world of illusion to reality. This would make the play obviously redundant. Second, in spite of the fact that the text seems to breach the laws of history and geography and make the time of Akbar and the Florence of Machiavelli collide in one place, there is no direct reference to the actual city of Florence at all; in fact, Akbar's image of it is permanently filtered through Niccolo Vespucci's story:

Akbar was walking the streets of that other stone city in which nobody seemed to want to stay indoors ... When solitude was banished, did one become more oneself, or less? Did the crowd enhance one's selfhood or erase it? [...] But Akbar's cloak was cut from the cloths of time and space and these people were not his. Why, then, did he feel so strong a sense of kinship with the denizens of these braying lanes? Why did he understand their unspeakable European tongue as if it were his own? (Rushdie 2008, 139-140; ellipsis in the original) 
In other words, it is only the fictional play put together by Vespucci's story that connects the two cultures and makes Akbar exclaim so many times in the novel that "the curse of the human race is not that we are so different from one another, but that we are so alike" (Rushdie 2008, 311). In the world of play where all the contraries and boundaries are nullified, languages are translated, cities are traveled through a fictional character's eyes, emperors can have paradoxical personalities, pirates can become emissaries of queens, East and West of different historical times can meet and people share the same dreams and aspirations. Rushdie himself confessed in his 2008 interview with Charlie Rose that he wanted to write a novel which would explore the differences between two worlds, but ended up demonstrating their similarities. In other words, in the space of play there is no difference between history and fiction.

Moreover, since in the same world reality and its representation are no longer separate, the story of Qara Köz and the episode with the Memory Palace are just means to establish the rules of the game, to create the "great matter of how the world joined up" that Rushdie mentioned in the interviews above. Significant in this respect is the motif of the mirror prevalent in the novel. D.C.R.A. Goonetilleke makes a rigorous inventory of the mirrors in the novel in his study on Rushdies's work and observes that "Qara Köz has her own Mirror" which towards the end of the novel is suspected to be Vespucci's mother; "the hero of Dashwanth's pictures became the emperor's mirror" (Goonetilleke 2010, 117). Apart from them, the critic discusses further on the mirrors of the artists and their models Dashwanth and Qara Köz, Filipepi/Botticello and Simonetta, Fatehpur Sikri and Florence as cities, Elizabeth I as the Western mirror of Akbar, and the lake Sikri as the mirror of the city. I would add the mirrors of Akbar and Vespucci and the writer himself as enchanters, of Akbar and Machiavelli as philosophers, and even the solitary mirror from the Medici castle which predicts the fate of Qara Köz once she ceases to enchant the city, and her presence becomes overly familiar. The mirror reflects the object without excluding it, and in the European cultural tradition, including in Romanticism, it has represented a means to reach the essences of the soul or to access higher knowledge. The essence reflected by the mirrors in Rushdie's novel refers to the relationship between the referent and its representation as the latter supports the existence of the first. Regardless of their historical or fictional nature, the characters in The Enchantress of Florence exist as long as they are talked about or represented, as long as they reflect in other characters' minds. It is the reason why Qara Köz has to leave Florence, it is what determines Johda's replacement, and also the reason for the beautiful, poetic promise at the end "until you're not, the Universal Ruler thought. My love, until you're not" (Rushdie 2008, 349), which speaks of the same threat of a possible replacement and symbolic death; this time referring to Angelica. Ultimately, this is the writer's/enchanter's and his novel's/play's most important 
role - to make these characters and events reflect in the minds of the readers and hold them under the spell of literature.

The same type of self-referentiality is present in what was seen as a downfall of the novel - the incest Niccolo Vespucci is supposedly a product of. As facile as it would stand for a prosaic explanation of the jump over time through which the plot operates, I think it suggests in fact the same idea of a self-sufficient novel, turned toward itself, following the rules of a play contained only within its limits and offered to the readers to be shared and reiterated with every new reading. After a long period of time in which literature in general and the novel in particular have been so bluntly denied originality and purpose, Rushdie's novel tends to return to its origins, to the point where, as I discussed at the beginning, "the visionary, the dream-poetry of the quotidian had not yet been crushed by blinkered, prosy fact" (Rushdie 2008, 10), in other words, the point where reality and the world of dreams and illusion were not yet separated. The story becomes a desire to re-establish a sacred world in which the two of them coexist, and the play as a suspension of logic can help the novel achieve that. That is why the writer sees no point in placing his work within the narrow boundaries of magical realism and defends its historical accuracy. The novel/play has its own substance which incorporates both of them and even makes them merge. The distinction between principal and secondary, historical progress versus literature, and all the terms associated with them (imperfection, defeat, etc.) is no longer necessary. Through this complicated labyrinth of play, the writer attempts to return to a primordial state in which literature had the sacred function of bringing people together under the spell of the storyteller, and this state is in my opinion symbolized in the novel by the element of water which even disappears from the city once the enchanter and his magic of language are gone. Thus, the end of the novel also marks the exit from this sacred world of play, a return to the "prosy" everyday life.

In fact, at a closer look, Rushdie actually fulfills the conservative role of the writer as Nemoianu defined it: in a time in which literary texts have become consumer objects and their importance has been under scrutiny, Rushdie tries to write novels that challenge how we see reality, how we define our place in history, and how we conceptualize otherness. It is a novel which returns to its former complexity and represents a world in itself, one in which characters are not plain textual beings, but they attempt to reconnect their readers to a complex archetype to which everyone can relate. As he declares in his book of memoirs, Joseph Anton, Rushdie misses the good novels of the past in which:

[a]ll writers and readers knew that human beings had broad identities, not narrow ones, and it was the breadth of human nature that allowed readers to find common grounds and points of identification with Madame Bovary, Leopold Bloom, Colonel Aureliano Buendia, Raskolnikov, Gandalf the Gray, 
[etc.]. Readers and writers could take that knowledge of broad-base identity out into the world beyond the pages of books, and use the knowledge to find common ground with their fellow human beings. (Rushdie, 2012, 627)

More exactly, in his writings in general and in The Enchantress of Florence in particular, Salman Rushdie tries to help the novel as a genre regain some of its lost grandeur, and this is probably the very reason why his work will last in time.

\section{Works Cited}

Anthony, Andrew. 2008. "The Bookers' Favourite." The Observer 5 April: n. p. (Last accessed 25 October 2015)

Conrad, JoAnn. 2009. "The Enchantress of Florence. By Salman Rushdie." Marvels \& Tales: Journal of Fairy-Tale Studies 23.2: 433-436.

Corrigan, Marianne. 2013. "Chapter Three. Rushdie as an International Writer: The Ground Beneath Her Feet, Fury, Shalimar the Clown and The Enchantress of Florence." In Salman Rushdie: Contemporary Critical Perspectives, eds. Eaglestone, Robert, and Martin McQuillan, 34-44. London, New Delhi, New York, Sydney: Bloomsbury.

Deresiewicz, William. 2008. "Meetings, Purchases, Pleasures." The Nation 287.7 15 September: 33-36. (Last accessed 15 November 2015)

Eaglestone, Robert, and Martin McQuillan, eds. 2013. Salman Rushdie: Contemporary Critical Perspectives. London, New Delhi, New York, Sydney: Bloomsbury.

Goonetilleke, D.C.R.A. 2010. "The Enchantress of Florence (2008)." Salman Rushdie. Second ed., 177-185. New York: Palgrave MacMillan.

Hitchens, Christopher. 2008. "Cassocks and Codpieces." Atlantic 302.1: 135-38. Literary Reference Center. (Last accessed 15 November 2015.)

Huizinga, Johan. 1950. "Chapter I: Nature and Significance of Play as a Cultural Phenomenon," 1-28, "Chapter VII: Play and Poetry." 119-136. In Homo Ludens: A Study of the Play-element in Culture. New York: Roy.

Hutcheon, Linda. 2002. The Politics of Postmodernism. London and New York: Routledge.

Malik, Kenan. 2013. "Foreword." In Salman Rushdie: Contemporary Critical Perspectives, eds. Eaglestone, Robert, and Martin McQuillan, vii-x. London, New Delhi, New York, Sydney: Bloomsbury.

Martino, Andrew. 2009. "The Enchantress of Florence." World Literature Today 83.1 (Jan/Feb): 70-71. Literary Reference Center. (Last accessed 20 November 2015) 
Nemoianu, Virgil. 2006. Imperfection and Defeat: The Role of Aesthetic Imagination in Human Society. Budapest: Central European UP.

Neuman, Justin. 2008. "The Fictive Origins of Secular Humanism.” Criticism 50.4 (Fall): 675- 82. Literary Reference Center. (Last accessed 15 November 2015)

Rose, Charlie. 2012. "Interviews." Salman Rushdie Archive. 9 April 2012: n. p. (Last accessed 15 November 2015)

Rushdie, Salman. 2008. The Enchantress of Florence: A Novel. New York: Random House.

Rushdie, Salman. 2012. Joseph Anton: A Memoir. New York: Random House.

Siegel, Robert. 2008. "Rushdie's Latest Novel Blurs Imagination, History.” NPR. 27 May: n. p. (Last accessed 15 November 2015)

Sutherland, John. 2008. "Of Medicis and Mughals.” Financial Times 5 April 5: n. p. (Last accessed 15 November 2015)

Thomsen, Mads Rosendahl. 2008. "Migrant Writers and Cosmopolitan Cultures." In Mapping World Literature: International Canonization and Transnational Literatures, 61-103. London: Continuum.

Tucker, Martin, ed. 2008. "The Enchantress of Florence.” Confrontations 102/103 (Winter): 212-214. (Last accessed 19 November 2015) 